years before Bernoulli's essay eventually appeared in print. Bernoulli's motivation to add this formula in the final version (prepared in 1765) was explicitly to show the superiority of his 'exact' approach over the crude estimate of d'Alembert, according to whom the proportion of susceptible individuals was "much less than half".

The reason why Bernoulli's important formula has escaped notice for so long may be its cryptic presentation: one has to recover it by substituting his numerical values with their general symbols. In formulating his laudable objectives, however, he is admirably clear: "I simply wish that, in a matter which so closely concerns the well-being of mankind, no decision shall be made without all the knowledge which a little analysis and calculation can provide."

Klaus Dietz ${ }^{\star}$, J. A. P. Heesterbeek $\dagger$

${ }^{*}$ Department of Medical Biometry, University of

Tübingen, 72070 Tübingen, Germany

†Centre for Biometry, PO Box 16, 6700 AA

Wageningen, The Netherlands

1. Bernoulli, D. Mém. Math. Phys. Acad. R. Sci. Paris 1-45 (1766); English translation by Bradley, L. in Smallpox Inoculation: An Eighteenth Century Mathematical Controversy (Adult Education Department, Nottingham, 1971).

2. Anderson, R. M. \& May, R. M. Infectious Diseases of HumansDynamics and Control (Oxford University Press, Oxford, 1991).

Dietz, K. Stat. Meth. Med. Res. 2, 23-41 (1993).

4. D’Alembert, J. Opuscules Mathématiques, t. II (Paris, David, 1761).

\section{Aquaculture: part of the problem, not a solution}

Sir-Aquaculture is claimed to aid the production of large quantities of low-cost protein-rich food to help feed the world, and to diminish pressure on ocean fisheries. In our opinion, neither of these claims is justified.

First, except in some parts of Asia, the main purpose of aquaculture has been to produce a luxury product for those who can afford to pay high prices. Second, Naylor et al. ${ }^{1}$ analysed the consequences of aquaculture practices and indicated that the growth of global production of farmed fish and shellfish will not relieve pressure on ocean fisheries.

Naylor et al. also indicated that aquaculture can diminish world fisheries indirectly by habitat modification, collection of wild seedstock, food-web interaction, nutrient pollution and the introduction of exotic species. However, in this last factor the authors referred only to possible hybridization between farm escapees and wild populations of Atlantic salmon, and to the spreading of pathogens. We believe it is also necessary to consider other consequences of introducing nonindigenous organisms, such as the elimination of autochthonous species by altering food webs, competition, hybridization and so on.

For scientists in developing countries such as ourselves, this point is of great importance. We would like to call to the attention of international organizations such as the World Bank, the International Development Bank and the Food and Agriculture Organization (FAO) the need to stop promoting aquaculture as a means of obtaining income from exports, and to concentrate on producing food for poor people. These organizations should stop promoting technological packages using exotic species and instead help the development of culture technologies for native species with the potential for aquaculture.

To give some examples: the FAO approved a technical cooperation project in Venezuela to genetically improve red tilapia, an unnecessary waste of resources that was a total failure ${ }^{2}$. The International Development Bank is partially financing a programme to culture exotic species in Panama, including the scallops Argopecten purpuratus, the cachamas Colossoma macropomus and Piaractus brachipomus, the channel catfish Ictalurus punctatus, the Sergeant or Peacock bass cichlid Cichla ocellaris, the giant prawn Macrobrachium rosenbergii and the bullfrog Rana catesbiana.

The World Bank finances several programmes in Latin America (see http://www.worldbank.org) introducing species such as Litopenaeus vannamei and L. stylirostris into countries where they do not occur naturally. In one Honduran project, the World Bank claims there is no risk of introducing alien species because the shrimps L. vannamei and L. stylirostris occur naturally there, in the Gulf of Fonseca. But it does not mention the risk of introducing alien species in a Venezuelan project which also uses L. vannamei, although they are not native to that region.

Aquaculture can make unique contributions to world nutrition, thanks to its extremely high productivity in many situations and to the fact that aquatic crops are primarily protein rather than starch. Certain aquatic organisms may be better at converting primary foods than ruminants, fowl or even pigs. Some, such as filterfeeding fishes and molluscs, feed on microscopic plankton that cannot be used directly for human food.

However, if the aquaculture industry is going to reduce the pressure on wild fish stocks and provide food for the world's growing population, substantial changes must be made by governments, the private sector and international funding agencies. They must protect coastal ecosystems; promote research and development of native species; and encourage farming of low-trophic-level fish - those low on the food chain. International technical funding agencies can exert great influence in changing practices. Otherwise, as Naylor et al. point out, an expanded aquaculture industry poses a threat, not only to ocean fisheries, but also to itself.

Julio E. Pérez ${ }^{\star}$, Mauro Nirchio $\dagger$, Juan A. Gomez

${ }^{*}$ Instituto Oceanografico, Universidad de Oriente,

Cumaná, Venezuela

$\dagger$ Escuela de Ciencias Aplicadas del Mar,

Universidad de Oriente, Isla de Margarita,

Venezuela

$¥$ Centro de Ciencias del Mar y Limnológia,

Universidad de Panamá, Panamá

1. Naylor, R. L. et al. Nature 405, 1017-1024 (2000).

2. Perez, J. E., Gomez, A. \& Nirchio, M. Interciencia 24, 321-323 (1999).

3. Programa de Modernización de Servicios Agropecuarios. Componente Acuicultura (Inter-American Development Bank, Panamá, 1995). http://www.iadb.org/EXR/doc98/ apr/lcpanaq.htm

\section{Funding would prevent waste of research time}

Sir - It has become clear over the last decade that doing research in Spain is quite a heroic task (see, for example, Nature 407, $428 \& 941 ; 2000)$. Poor funding and lack of prospects for young researchers are among the many obstacles that have precluded the rise of Spanish science to the very top. Although an increase in the amount of money devoted to research is an obvious prerequisite, the many problems that young investigators face haven't been analysed in detail.

A numerical comparison with our EU counterparts (not to mention with the United States and Japan) shows the need to create positions to absorb many of the excellently trained postdocs that Spain has sent abroad during the past 15 years. But nobody is discussing the conditions under which these new hirings should take place. The fact is that Spain has no policy of providing start-up packages for the newly hired group leaders. This has unfortunate consequences, as new researchers sit in their offices (if they have offices) and begin chasing grants for a period of up to three years, losing all continuity with their research projects.

If Spain is to have a core of young investigators doing science at its best, these scientists should be provided not just with positions but also with funding for research. Otherwise, talent is wasted, again. Pedro Martínez

Department of Anatomy and Cell Biology, University of Bergen, Aarstadveien 19,

5009 Bergen, Norway 